\title{
THE SECOND BOOK OF THE RHYMERS' CLUB
}

\section{BY GEORGE HELD}

Mr. HeLd, who holds a master's degree from the University of Hawaii, is now a graduate student in the English Department of Rutgers University.

$7 H E$ Second Book of the Rhymers' Club, published in a limited edition in I 894, has become a collector's item. Only five hundred copies, four hundred for sale, were produced for England; one hundred and fifty for sale in America. The Rutgers University Library is fortunate to own a copy, which is housed in its rare book collection. The sixteenmo volume, bound in brown cloth, contains pp. XVI + I36. The book includes the work of thirteen poets, all members of the Rhymers' Club, an important literary group during the Aesthetic Nineties.

The Rhymers' Club was begun in I89I; accounts vary about who founded it. In his Autobiography William Butler Yeats says that he and Ernest Rhys began it; Rhys himself names T. W. Rolleston as a third founder. At any rate, the Rhymers met irregularlysometimes on several consecutive nights, sometimes only once in several weeks-until the summer of I 894, when its diverse membership went their various ways. The primary interest of the Rhymers was, of course, poetry. Yeats and his co-founders hoped that by reading their verses to their assembled colleagues, and by exchanging suggestions and criticism, they might improve their work. Yeats was to be disappointed in this, however, for in the Autobiography he relates that "the meetings were always decorous and often dull; some one would read out a poem and we would comment, too politely for the criticism to have great value; and yet that we read out our poems, and thought that they could be so tested, was a definition of our aims." Arthur Symons, one of the Club's better known members, recalls that these poets made a "desperate and ineffectual attempt to get into key with the Latin Quarter." For men like Symons, influenced by the French writers,

${ }^{1}$ Arthur Symons, "Ernest Dowson," The Poems of Ernest Dowson (London: John Lane, The Bodley Head, I905), p. viii. 
the Club offered an opportunity to emulate life in Paris, where "it is the most natural thing in the world to meet and discuss literature, ideas, and one's own and one another's work."

One characteristic of the Rhymers' Club was its informality of organization. It was "a club without rules or officers," though George Arthur Greene acted as its honorary secretary. A list in Greene's handwriting includes, nearly alphabetically, the following members: John Davidson, Ernest Dowson, Edwin J. Ellis, George Arthur Greene, Lionel Johnson, Arthur Cecil Hillier, Richard Le Gallienne, Victor Plarr, Ernest Radford, Ernest Rhys, Thomas Wm. Rolleston, Arthur Symons, John Todhunter, Wm. Butler Yeats. Of these Davidson contributed to neither of the Rhymers' books and Hillier to just The Second Book of the Rhymers Club. In addition to the listed members, the Club "at one time affiliated to itself the following permanent guests:- John Gray, Edward Rose, J. T. Nettleship, Morley Roberts, A. B. Chamberlain, Edward Garnett, and William Theodore Peters." Also, Yeats recalls that Selwyn Image, Herbert Horne, and William Watson were members, and that "Francis Thompson came once but never joined; and sometimes . . . Oscar Wilde came." The novelist Ernest Jepson was another infrequent guest.

The membership of the Rhymers' Club was diverse in several respects. First of all, the men ranged in age from twenty-three (Johnson and Dowson) to fifty-two (Todhunter). Secondly, they came from a variety of backgrounds. John Davidson, for example, was a Scotsman who had been a school teacher. Ernest Rhys was a Welshman who had lately been a mining engineer. Yeats had been born and raised in Ireland and had attended "art school instead of a university," but in his words "most of . . . [the Rhymers] had ... been to Oxford and Cambridge." While Lionel Johnson was a man of private means, according to Yeats, the majority of the Rhymers were rather poor.

The differences in age and background made the Rhymers susceptible to different influences. Among these Yeats stresses Rossetti

2 Ibid., p. ix.

${ }^{3}$ Victor Plarr, Ernest Dowson, $1888-1897$ (New York: Laurence J. Gomme, I9i4), p. I 33 .

${ }^{4}$ Ibid. $\quad{ }^{5}$ Ibid. 
- "a subconscious influence, and perhaps, the most powerful of all" -and Pater, to whom "we looked consciously ... . for our philosophy." Other important influences on the group were Paul Verlaine, along with the other French symbolists, and the Celtic heritage of some of its members, including Todhunter, Plarr, Johnson, and Symons.

Despite the several influences that no doubt affected the Club, the Rhymers were too heterogeneous a group to be classified as the representative of any particular aesthetic movement of their day. One of the group, Richard Le Gallienne, writes tellingly on this point:

It had none of the propagandizing significance of other such clubs of poetic revolutionaries before or since, and, as a body, was not an energetic institution, nor of long life. Its members lacked any common fusing artistic ideal such as has animated, say, the subsequent imagist movement. Each was doing his own work in his own way, and the significance of the club was in its individuals rather than in any collective character. ${ }^{\circ}$

Also to the point here is that no one in the group had as yet achieved any large degree of fame, and no one unduly exerted the influence of a leader.

The meetings of the Rhymers' Club were most often held, Yeats tells us, "in an upper room with a sanded floor in an ancient eatinghouse in the Strand called The Cheshire Cheese," where in an earlier day Dr. Samuel Johnson had eaten. Here "long clay pipes lay in heaps on the wooden tables, between tankards of ale; and young poets, then very young, recited their own verses to one another...."

Simply to recite and criticize poetry was not enough for Yeats, it seems. He wished to discuss the larger ideas of philosophy and poetic theory, but, he laments, "the one conviction shared by all the younger men ... was an opposition to all ideas, all generalizations that can be explained and debated." As a result of these conflicting points of view, he continues, "conversation continually dwindled into 'Do you like so and so's last book?' 'No, I prefer the book before it. ..."”

\footnotetext{
${ }^{6}$ Richard Le Gallienne, The Romantic 'go's (London: Putnam \& Co., I95I), pp. ro8-rog.

7 Symons, p. viii.
} 
The visible fruits of the Rhymers' Club are contained in two small volumes. At the suggestion of Yeats, who had heard but never seen some of the poems of his colleagues, the Rhymers collaborated in publishing The Book of the Rhymers' Club in I 892 . Like the Club itself, the book "had no prevailing tone. It had no purpose beyond bringing together in friendly association, after the manner of such old miscellanies as 'England's Helicon' or Davison's 'Poetical Rhapsody,' examples of the work of twelve poets . . . who had constituted themselves a very informal club. . . " For the purpose of publishing the book, the contributors drew up with the publishers, Elkin Mathews and John Lane, a plan whereby the "expenses and profits were to be divided in accordance with the space taken by each contributor." Only three hundred and fifty copies of The Book of the Rhymers' Club were issued, in the fall of 1892 , and all copies had been sold at the end of a few months.

The twelve poets whose work appeared in the volume include Dowson, Ellis, Greene, Johnson, Le Gallienne, Plarr, Radford, Rhys, Rolleston, Symons, Todhunter, and Yeats. By agreement there was to be a limit of six poems per man, and "only Dowson, Johnson, Rhys, Yeats, and Greene had the maximum . .."10 number appear in the ninety-four page volume. The most noteworthy pieces included are Johnson's "By the Statue of King Charles at Charing Cross," Dowson's "Villanelle of Sunset," and Yeats's "The Lake Isle of Innisfree." Despite the excellence of these poems, it is the opinion of Mark Longaker "that the quality of the contributions to the volume was not always high. The variety of themes and manners, and the wide differences in quality of the fifty-seven pieces which formed the contents bear out the statement that the Rhymers' Club had little in common save their general interest in verse." ${ }^{11}$ Nevertheless, The Book of the Rhymers' Club achieved both critical and popular acceptance.

The success of this volume no doubt helped to provide the Rhymers with the stimulus to continue the Club. Soon they projected

${ }^{8}$ Le Gallienne, p. 108.

${ }^{9}$ Mark Longaker, Ernest Dowson (Philadelphia: University of Pennsylvania Press, I944), p. 96.

${ }^{10}$ Ibid., p. 98.

11 Ibid., p. I 00. 
another book under much the same terms as the first, and in I 894 Mathews and Lane published The Second Book of the Rhymers Club. This volume comprises the work of the twelve men who published in the first book, and one other, T. W. Rolleston. Among the better known of the seventy-three poems in the second book are Dowson's "Extreme Unction" and "Non sum qualis eram bonae sub regna Cynarae," Johnson's "To Morfydd," and Yeats's "The Rose of Peace," "The Fiddler of Dooney," and "The Cap and Bells." Some of the poems in the volume had been published previously in magazines, including The Spectator, The Bookman, and Macmillan. Such was the case, for example, with Dowson's "Cynara," which had first appeared in the April I 89I issue of The Century Guild Hobby Horse.

The verse forms employed in this collection are largely traditional, with wide use made of the quatrain and conventional rhyme schemes. The Petrarchan sonnet is Greene's favorite form; the ballad stanza has an exponent in Yeats.

As with the first book, The Second Book of the Rhymers' Club is marked by its diversity of style, subject, and quality. In style many of the poems are romantic, carrying on a long poetic tradition. Romantic characteristics are to be observed, for example, in this pair of lines from Edwin Ellis' "A Year of the River":

The Spring is here, the Spring is free

From bonds of Winter's jealousy. . . .

The aura of the decadents is present in John Todhunter's "Euthanasia," in which "some languorous nepenthe" is sought amidst the splendors of perfumes and a lover's kisses. Arthur Hillier's "The Memorial Garden" is also decadent, containing a stanza similar in mood and image to the garden scenes in Oscar Wilde's The Picture of Dorian Gray:

Half-sated with the petalled chalice fair,

Yet thieving still,

A roaming bee hums through the hot sweet air

To poise at will.

In sharp contrast to such lushness are both the style and the subject of G. A. Greene's "A Mood." At first soberly, then bitterly 
contemplating the contemporary loss of faith, Greene's poem concludes on a note of despair:

Prayer, and the Cross we adored-

All is lost! there is no one above:

We are left like the beasts that creep:

They have taken away our Lord.

This religious poem juxtaposed to the romantic and decadent ones above attests to the diversity of poetic interests and tastes among the Rhymers. The Second Book of the Rhymers' Club also contains poems on Welsh folklore, such as Ernest Rhys's "To O. E." and "Howel the Tall," topical poems such as Todhunter's "In Westminster Abbey" and Le Gallienne's "A Ballad of London," and verses inspired by classical subjects, such as Ellis' "On Venus" and Greene's "Proserpine." One Rhymer, Ernest Radford, was interested in the social reform activities of his day, as shown by these lines from "Song in the Labour Movement":

Oh, you whose sluggard hours are spent

The rule of Mammon to prolong

What know you of the stern intent

Of hosted labour marching strong?

The quality of the verse in this book varies almost as widely as the themes. Some of the bad verse is illustrated by this stanza from Arthur Symons' "Song":

And I think, if Love has missed

Shelter in the wintry waste,

That this heart may soon prepare

Some nook for him to nestle there.

Even worse, no doubt, is this excerpt from Le Gallienne's "An Ode to Spring":

But see how yonder goes,

Dew-drunk, with giddy slant

Yon Shelley-lark

And hark!

Him on the giddy brink

Of pearly Heaven

His fairy anvil clink. ... .

The bad verse in the collection is to a large degree offset by the 
excellence of those better known poems that have been mentioned above. Probably the most famous among them is Dowson's "Cynara," which Arthur Symons called one of our greatest lyrical poems.

With the publication of the second book, the Rhymers' Club had spent its usefulness. When the members departed for their holidays in the summer of I 894, "meetings were given up; and by the autumn no one apparently was sufficiently energetic to bring the group together again as a club." "12 As Yeats recalls it, "the Rhymers had begun to break up in tragedy, though we did not know that till the play had finished. I have never found a full explanation of that tragedy. ..." Perhaps part of the explanation for the break-up is touched upon in Yeats's comments, quoted earlier, about the members' conflicting attitudes toward ideas and about the way their conversations often degenerated into the trivial. Then again the great diversity of the membership always bore within it the seeds of dissolution.

Thus the Rhymers' Club existed; it served its purpose; and it died. Some of its members achieved fame; most faded into obscurity. Perhaps a fitting tribute and epitaph for the Club might be these lines by the most famous Rhymer of them all, William Butler Yeats:

You had to face your ends when young-

'Twas wine or women, or some curse-

But never made a poorer song

That you might have a heavier purse,

Nor gave loud service to a cause

That you might have a troop of friends.

You kept the Muses' sterner laws

And unrepenting faced your ends. . . .

12 Ibid., p. 106. 